\title{
Infectious Disease Research-What Role Is There for Hydrologists?
}

\author{
Kristina Heinrich1, Martin Bach1, Lutz Breuer1,2* \\ ${ }^{1}$ Institute for Landscape Ecology and Resources Management (ILR), Research Centre for Bio Systems, Land Use and \\ Nutrition (iFZ), Justus Liebig University Giessen, Giessen, Germany \\ ${ }^{2}$ Centre for International Development and Environmental Research (ZEU), Justus Liebig University Giessen, Giessen, Germany \\ Email: *lutz.breuer@umwelt.uni-giessen.de
}

How to cite this paper: Heinrich, K., Bach, M. and Breuer, L. (2017) Infectious Disease Research-What Role Is There for Hydrologists? Journal of Water Resource and Protection, 9, 139-162.

https://doi.org/10.4236/jwarp.2017.92011

Received: November 30, 2016

Accepted: February 3, 2017

Published: February 6, 2017

Copyright $\odot 2017$ by authors and Scientific Research Publishing Inc. This work is licensed under the Creative Commons Attribution International License (CC BY 4.0).

http://creativecommons.org/licenses/by/4.0/

\begin{abstract}
Numerous virulent and widespread diseases are related to water. The transmission and outbreak of water-related diseases are closely coupled to their hydrological environment. Changes in this environment and the associated hydrological processes may affect the occurrence and virulence of waterrelated diseases. Environmental changes can be manifold, including e.g. climate and land use, agricultural management or urbanization. Water fluxes and storages play a dominant role in describing disease outbreak, transmission and transport. New land cover types often alter landscape scale water storages. If the effects of changes could be better understood, predictions about the distribution, emergence or outbreak of water-related diseases would be possible. Furthermore, the collaboration of experts from different disciplines is essential for accurate spatial and temporal prediction of water-related disease outbreaks. Here we review the current state of knowledge of waterrelated diseases and present a general classification of these diseases, followed by a discussion of their major drivers. This review focuses particularly on hydrologists and how they can contribute with their understanding of hydrological processes.
\end{abstract}

\section{Keywords}

Water-Related Diseases, Climate Change, Irrigation, Land Use Change, Population Growth

\section{Introduction}

Water plays an important role in infectious disease transmission worldwide. Many virulent and widespread diseases are related to water. According to the WHO World Malaria Report 2015, there were an estimated 214 million cases of 
malaria worldwide in 2015 [1] and an estimated 218 million people required preventive treatment for schistosomiasis in 2015 [2]. Infectious diseases and their outbreaks are driven and otherwise affected by water through the impact of water on various developmental stages and habitats of hosts, vectors and pathogens. This impact occurs through two primary means: 1 ) the natural hydrological cycle including patterns and timing of rainfall, and 2) ecosystem changes that have arisen from human alterations of the environment. In general, the understanding of the role of water as a driver for pathogen location, survival, and transmission is crucial for the management and alleviation of the effects of infectious diseases on humans.

Research on individual drivers, components and processes within systems is necessary to define the direct effects as well as the feedback loops that exist between humans, developed landscapes (e.g. urban areas, agricultural land) and natural systems. These aspects become particularly important in the face of two major contemporary drivers of disease transmission and outbreak: increasing population and global climate change. The former places particular stress on water systems through the increasing need for water. The ratio of water use to available supply has grown by $20 \%$ per decade since 1960 [3]. Global climate change can affect water systems in ways that have the potential for significant consequences on human health and well-being. According to the 5th Assessment Report by the IPCC the average temperatures will increase, the global average sea level will rise and extremes in the hydrological cycle will grow [4].

In this discussion paper, we address some basic aspects for hydrologists to contribute to a better understanding of the interactions between hydrology and infectious agents and pathogens. While disease outbreaks and transmissions are clearly more related to epidemiology, hydrological conditions, processes and fluxes are direct and indirect drivers for hosts and vectors. If we want to improve our understanding of the role that hydrology and the hydrologic cycle play in determining the prevalence and spread of infectious diseases, particularly with regard to expected changes in global climate, there are several topics that deserve further research. In general, models should aim at linking host-vector interactions of the water-related disease with the environmental conditions, i.e. the direct drivers that are associated with hydrology. We will first classify waterrelated diseases with regard to their transmission routes and discuss the current state of some of the most important water-related diseases which are reliant on water-related vectors or intermediate hosts. We then present the major drivers of water-related diseases and show, finally, where hydrological science can contribute to a better understanding of disease transmission and outbreaks.

\section{Infectious Diseases Related to Water}

The number of water-related diseases is numerous, and there is no consensus on how to exactly define which diseases should be classified as water-related diseases and which not. The WHO lists 25 diseases which they classify as "water-related", and provide information sheets for each [5]. A helpful classification 
system presented by the National Academy of Sciences (U.S.) (NAS) divides water-related diseases into five categories based on their transmission route: diseases caused by poor sanitation, those that are waterborne, water-washed, waterbased, and those that rely on water-related insect vectors [6].

The first three disease groups can be controlled through appropriate access to adequate and clean drinking water, as well as to proper sanitation facilities that eliminate fecal and urinary contamination of water resources and soils. Despite major achievements since 1990 even today more than 2.5 billion people lack access to improved sanitation and 0.768 billion people do not have access to safe drinking water [7]. While improvements remain a challenge for most developing countries, it is not primarily a question of scientific research: sufficient amounts of water along with education about safe food and personal hygiene could significantly reduce the incidence and impact of these diseases. Half of the urban population in Africa, Asia, Latin America, and the Caribbean still suffer from one or more diseases due to lack of clean water and insufficient sanitation conditions [3]. About 1.7 million people die annually worldwide as a result of inadequate water supplies, poor sanitation, and hygiene [3].

In contrast, the last two disease groups involve more complex transmission patterns and intrinsic interactions of vectors, hosts and pathogens at various spatial (from local scale to landscapes) and temporal scales. These disease groups are the focus of this review. Therefore, in the following they are discussed in more detail.

\subsection{Diseases Caused by Poor Sanitation}

These diseases result directly from the lack of adequate sanitation [6] [8] [9]. Examples for pathogens which spread through poor sanitation are whipworms, whose eggs may persist on food grown in contaminated soil (transmitted by a fecal-oral route), and hookworms, which spread from contaminated soil directly through the soles of the feet [10]. An increasingly important transmission route for these kinds of diseases is also related to the reuse of wastewater in irrigation agriculture to save water resources (e.g. groundwater) [11] [12].

\subsection{Waterborne Diseases}

Waterborne diseases are spread via the fecal-oral transmission route through the ingestion of contaminated water or food that was in contact with contaminated water [6]. Some of the best-known and most widespread diseases are waterborne. Cholera and typhoid are caused by bacteria, cryptosporidiosis and giardiasis are caused by protozoans, and hepatitis A and E are caused by viruses.

\subsection{Water-Washed Diseases}

Water-washed diseases do not rely on a fecal-oral route but are spread personto-person. They can be controlled through adequate water supplies that permit sufficient personal hygiene [6]. Examples of these include trachoma, a bacterial infection of the eyes, and scabies [13], a parasitic skin infection. 


\subsection{Water-Based Diseases}

Water-based diseases (Table 1) are spread through aquatic organisms and, thus, are intimately tied to hydrologic cycles [6]. Populations of vectors or hosts can be affected by natural changes in water conditions as well as by human-induced changes to water systems.

\subsubsection{Schistosomiasis}

Schistosomiasis is caused by different Schistosoma species, of which $S$. mansoni (endemic in Africa and South America), S. japonicum (endemic in China, Indonesia and the Philippines) and $S$. haematobium (endemic in Africa and the Middle East) are the most important [14] [15]. While $S$. mansoni and $S$. japonicum cause intestinal schistosomiasis, the species $S$. haematobium causes urogenital schistosomiasis. 193 million people were infected with schistosomiasis in the mid-1990s [16], while [17] estimates that 207 million people were infected in 2003. The lifecycle of the human pathogen schistosomes requires a human host and different types of fresh water snails (Table 2) as intermediate host [18]. Skin or mucous membrane contact with contaminated water infects humans. The cercaria (larva stage of schistosomes), which are contained in the water, penetrate the human skin. In the end, Schistosoma eggs pass again into the water via stool or urine of the infected humans [14].

Table 2 shows biological characteristics and the preferred habitats of the different host snails. Potential biological snail control measures include the removal of aquatic plants, or the protection of the snails' natural predators [19] [20]. The availability of clean water and improved sanitation is also important for the control of the disease [16] [21]. It is possible to reduce the prevalence of schistosomiasis with control programs but in some regions, primarily in Africa, where control programs were undertaken and/or irrigation projects were introduced, schistosomiasis remains a problem [16]. Regarding potential treatment of schistosomiasis, the anthelmintic praziquantel, which has been available since 1988, is widely used [18].

Table 1. Transmission route, hydrologic interaction, and prevention methods of major water-based diseases.

\begin{tabular}{|c|c|c|c|}
\hline Disease & Agent, vector and transmission route & $\begin{array}{l}\text { Hydrologic } \\
\text { interaction }\end{array}$ & Prevention \\
\hline Schistosomiasis & $\begin{array}{l}\text { Infection by flatworm; worm larvae } \\
\text { develop in freshwater snails and } \\
\text { penetrate through human skin; infected } \\
\text { humans transmit eggs through feces } \\
\text { or urine which in turn infect snails }\end{array}$ & $\begin{array}{l}\text { Host snails } \\
\text { prefer standing } \\
\text { or slow flowing } \\
\text { waters; affected by } \\
\text { irrigation projects }\end{array}$ & $\begin{array}{c}\text { Improved } \\
\text { sanitation, safe } \\
\text { water access; } \\
\text { prevention } \\
\text { and control } \\
\text { of snail vectors }\end{array}$ \\
\hline Dracunculiasis & $\begin{array}{l}\text { Infection by roundworm; worm larvae } \\
\text { ingested by and developed in water } \\
\text { fleas. Ingestion of contaminated water, } \\
\text { fleas release larva into human } \\
\text { body where worms mature }\end{array}$ & $\begin{array}{l}\text { Worm larvae } \\
\text { ingested by and } \\
\text { developed in } \\
\text { water fleas }\end{array}$ & $\begin{array}{l}\text { Safe drinking } \\
\text { water supplies, } \\
\text { filtering of water }\end{array}$ \\
\hline
\end{tabular}


Table 2. Biology of the snail hosts of different schistosomiasis species, based on [20] with additions from [26].

\begin{tabular}{|c|c|c|c|}
\hline \multirow{2}{*}{$\begin{array}{l}\text { Biological } \\
\text { facts }\end{array}$} & \multicolumn{3}{|c|}{ Snail hosts of different Schistosoma species } \\
\hline & $\begin{array}{c}\text { Bulinus } \\
\text { (S. haematobium) }\end{array}$ & $\begin{array}{l}\text { Biomphalaria } \\
\text { (S. mansoni) }\end{array}$ & $\begin{array}{l}\text { Oncomelania } \\
\text { (S. japonicum) }\end{array}$ \\
\hline $\begin{array}{l}\text { Relation } \\
\text { to water }\end{array}$ & Entire lifecycle in water & Entire lifecycle in water & $\begin{array}{c}\text { Entire lifecycle } \\
\text { in water, lives near } \\
\text { water (amphibious) }\end{array}$ \\
\hline $\begin{array}{l}\text { Preferred } \\
\text { habitat }\end{array}$ & $\begin{array}{l}\text { Slow flowing or standing } \\
\text { waters like irrigation } \\
\text { ditches, lakes, ponds, rivers } \\
\text { and wetland rice cultivation }\end{array}$ & $\begin{array}{l}\text { Slow flowing or standing } \\
\text { waters like irrigation } \\
\text { ditches, lakes, ponds, rivers } \\
\text { and wetland rice cultivation }\end{array}$ & $\begin{array}{l}\text { Muddy banks } \\
\text { from ditches, lakes, } \\
\text { rivers and wetland } \\
\text { rice cultivation }\end{array}$ \\
\hline Food & Aquatic plants & Aquatic plants & Mud with e.g. algae \\
\hline $\begin{array}{l}\text { Resistance } \\
\text { to } \\
\text { desiccation }\end{array}$ & $\begin{array}{l}\text { Good, survives for } 7 \\
\text { month buried in the soil }\end{array}$ & Less good & Very good in mud \\
\hline Embryonic & $\begin{array}{c}\text { At } 25^{\circ} \mathrm{C} \text { about } 7 \text { - } 8 \text { days, } \\
\text { sexually mature } \\
\text { after } 1 \text { month }\end{array}$ & $\begin{array}{l}\text { At } 25^{\circ} \mathrm{C} \text { about } 7 \text { - } 8 \text { days, } \\
\text { sexually mature } \\
\text { after } 1 \text { month }\end{array}$ & $\begin{array}{l}\text { At } 25^{\circ} \mathrm{C} \text { about } 18-20 \\
\text { days, sexually mature } \\
\text { in nature after } \\
\text { about } 5 \text { months }\end{array}$ \\
\hline Life time & Slightly more than 1 year & Slightly more than 1 year & Years \\
\hline
\end{tabular}

\subsubsection{Dracunculiasis}

Dracunculiasis is caused by the guinea worm (Dracunculus medinensis), which needs water fleas as intermediate host [22]. People get infected by drinking water with infested water fleas (Cyclops species). When the infected part of the body gets into contact with water the worm larvae are released [18]. From almost a million incident cases in the middle of the 1980s, incidence dropped to below 2000 cases in the year 2009 [23]. The methods of elimination of dracunculiasis, which have been applied since 1982, include the provision of safe drinking water, the filtering of drinking water, and the treatment of water with Abate (which will kill Cyclops and is, therefore, an effective measure to prevent transmission) [22]. The case of dracunculiasis is an example of the success of a communitybased prevention and health education program that has contributed to the near eradication of this disease [25]. A good precondition for the eradication of the disease is that humans are the only known reservoir [18].

\subsection{Water-Related Insect Vector Diseases}

Also strongly affected by human alterations, as well as natural fluctuations, are diseases spread through water-related insect vectors (Table 3 ). These are diseases transmitted by insects who breed in, or whose lifecycles are tied to, particular water characteristics (Table 4) [6].

\subsubsection{Malaria}

Malaria is caused by different Plasmodium species which are transmitted between humans through Anopheles mosquitoes (Table 4). There are around sixty known species of Anopheles mosquitoes which are malaria vectors [27]. Most vectors breed in stagnant or slow flowing water [28]. There were approximately 
Table 3. Transmission route, hydrologic interaction, and prevention methods for major water-related insect vector diseases.

\begin{tabular}{|c|c|c|c|}
\hline Disease & $\begin{array}{l}\text { Agent, vector \& } \\
\text { transmission route }\end{array}$ & Hydrologic interaction & Prevention \\
\hline Malaria & $\begin{array}{l}\text { Plasmodium parasite, } \\
\text { transmitted by } \\
\text { mosquito bites }\end{array}$ & $\begin{array}{l}\text { Closely related to presence } \\
\text { of stagnant or slow flowing } \\
\text { water for breeding sites; } \\
\text { affected by irrigation } \\
\text { and water storage }\end{array}$ & $\begin{array}{l}\text { Mosquito } \\
\text { control } \\
\text { measures } \\
\text { including } \\
\text { reduction of } \\
\text { breeding sites } \\
\text { and prevention } \\
\text { of bites }\end{array}$ \\
\hline Dengue & $\begin{array}{l}\text { Virus, transmitted } \\
\text { by mosquito bites }\end{array}$ & $\begin{array}{l}\text { Stagnant waters preferred } \\
\text { breeding sites of mosquitoes }\end{array}$ & See above \\
\hline Zika virus & $\begin{array}{l}\text { Virus, transmitted } \\
\text { by mosquito bites }\end{array}$ & $\begin{array}{l}\text { Stagnant waters preferred } \\
\text { breeding sites of mosquitoes }\end{array}$ & See above \\
\hline $\begin{array}{l}\text { Japanese } \\
\text { encephalitis }\end{array}$ & $\begin{array}{l}\text { Virus, transmitted between } \\
\text { mosquitoes and pigs } \\
\text { and/or water birds }\end{array}$ & $\begin{array}{l}\text { Affected by agricultural } \\
\text { production techniques, } \\
\text { especially rice production }\end{array}$ & See above \\
\hline $\begin{array}{l}\text { West } \\
\text { Nile virus }\end{array}$ & $\begin{array}{c}\text { Virus, } \\
\text { transmitted in a } \\
\text { mosquito-bird-mosquito } \\
\text { cycle }\end{array}$ & $\begin{array}{l}\text { Stagnant waters preferred } \\
\text { breeding sites of mosquitoes }\end{array}$ & See above \\
\hline $\begin{array}{l}\text { Yellow } \\
\text { fever }\end{array}$ & $\begin{array}{l}\text { Virus, transmitted } \\
\text { monkey-to-monkey, } \\
\text { monkey-to-human or } \\
\text { human-to-human } \\
\text { by mosquitoes }\end{array}$ & $\begin{array}{l}\text { Stagnant waters preferred } \\
\text { breeding sites of mosquitoes }\end{array}$ & See above \\
\hline $\begin{array}{l}\text { Chikungunya } \\
\text { fever }\end{array}$ & $\begin{array}{l}\text { Virus, transmitted } \\
\text { by mosquito bites }\end{array}$ & $\begin{array}{l}\text { Stagnant waters preferred } \\
\text { breeding sites of mosquitoes }\end{array}$ & See above \\
\hline Rift Valley fever & $\begin{array}{l}\text { Virus, transmitted } \\
\text { between ruminants } \\
\text { by bites of mosquitoes }\end{array}$ & $\begin{array}{l}\text { Stagnant waters preferred } \\
\text { breeding sites of mosquitoes }\end{array}$ & See above \\
\hline $\begin{array}{l}\text { Onchocerciasis } \\
\text { (river blindness) }\end{array}$ & $\begin{array}{l}\text { Parasitic filarial worm, } \\
\text { transmitted between } \\
\text { humans by blackfly bites }\end{array}$ & $\begin{array}{l}\text { Blackflies lay eggs in } \\
\text { fast moving rivers }\end{array}$ & See above \\
\hline $\begin{array}{l}\text { Lymphatic } \\
\text { filariasis }\end{array}$ & $\begin{array}{l}\text { Parasitic filarial worm, } \\
\text { transmitted by } \\
\text { mosquito bites }\end{array}$ & $\begin{array}{l}\text { Stagnant and polluted } \\
\text { waters are preferred } \\
\text { breeding sites }\end{array}$ & $\begin{array}{l}\text { Mosquito } \\
\text { control } \\
\text { measures, } \\
\text { sanitation } \\
\text { improvements }\end{array}$ \\
\hline
\end{tabular}

Table 4. Association between selected mosquito vectors, their habitat, and the principal disease they transmit, based on [26] with additions compiled from [32] [33] [34] [35].

\begin{tabular}{cccccc}
\hline Vector & & $\begin{array}{c}\text { Culicine } \\
\text { mosquitoes } \\
(\text { Aedes, Culex })\end{array}$ & $\begin{array}{c}\text { Anopheline } \\
\text { mosquitoes } \\
(\text { Anopheles })\end{array}$ & $\begin{array}{c}\text { Simulid } \\
\text { blackflies } \\
(\text { Simulium })\end{array}$ \\
\hline \multirow{2}{*}{ Disease } & Arbovirus- & Dengue & $\mathrm{X}$ & & \\
& diseases: & Zika virus & $\mathrm{X}$ & \\
& & Yellow fever & $\mathrm{X}$ & \\
\hline
\end{tabular}




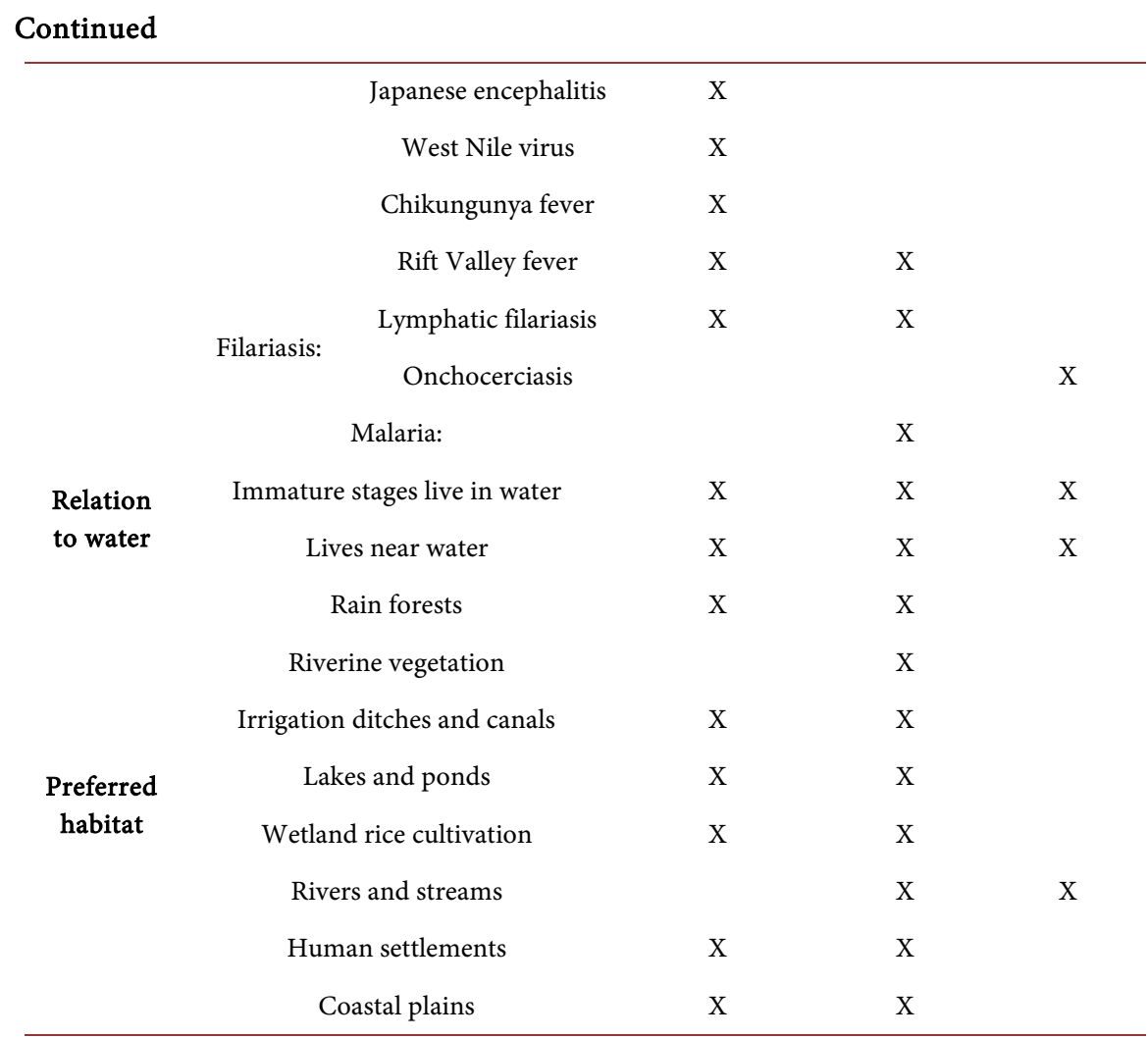

214 million cases of malaria in the year 2015 according to the most recent global estimate by the WHO [1]. It is estimated that the number of cases globally decreased from 262 million estimated cases in 2000 to 214 million in 2015 [1]. The number of cases deceased due to the impact of malaria control interventions [29]. Control interventions include treatment with an artemisin in-based combination therapy, environmental management measures to reduce breeding sites (i.e. change of habitat conditions) and mosquito control with insecticides [28] [30] [31].

\subsubsection{Dengue}

Dengue is a viral disease transmitted by Aedes mosquitoes (Table 4) (for example by $A$. aegypti and $A$. albopictus) [15]. It is endemic in tropical and subtropical regions. About one million confirmed cases of dengue are annually reported to the WHO [15]. The spread of the disease is increasing because of the advancing distribution of the mosquito vectors [15]. Factors like open water storage increase Aedes population densities and the transmission of Aedes-borne diseases like dengue, especially in urban areas [15]. Outbreak of the disease is tied to seasonal patterns such as heavy rain and humidity [36]. Dengue control measures include environmental management and mosquito control with insecticides [15].

\subsubsection{Zika Virus}

The Zika virus is a viral disease transmitted by Aedes mosquitos (especially $A$. aegypti) (Table 4). The natural transmission cycle involves mainly Aedes mos- 
quitoes and monkeys while humans become infected only coincidentally [37]. The virus is endemic in Africa and Asia and occurred in Brazil for the first time in 2015 [38]. Up to 1,300,000 people have been infected in Brazil (February 2016) and 29 other countries in the Americas have reported autochthonous Zika virus transmission [39]. Further spread into regions where mosquito vectors are present is likely because of air travel and international trade [38] [39]. Prevention measures include primarily vector control actions as no vaccination exists currently. Further research is needed, inter alia, to define the range of Zika virus vectors [39].

\subsubsection{Japanese Encephalitis}

The virus of the Japanese encephalitis exists in a zoonotic transmission cycle primarily between mosquitoes, pigs, and/or water birds [40]. Humans become infected only coincidentally when bitten by an infected mosquito. Japanese encephalitis is spread in most parts of Asia and Oceania, and with at least 30,000 50,000 cases developing each year [40]. It is mostly a rural disease caused by $\mathrm{Cu}$ lex tritaeniorhynchus mosquitoes (main vector), which breed in rice paddies (Table 4). The increasing amount of rice paddies and irrigation support the transmission of Japanese encephalitis [41]. Mosquito control, with environmental management like intermittent irrigation, is used to reduce breeding sites. Avoiding human exposure and immunization of humans are further interventions which work against the transmission of the disease [40].

\subsubsection{West Nile Virus}

Culex species mosquitoes are the primary vectors of the West Nile virus (Table 4), which exists naturally in a mosquito-bird-mosquito transmission cycle [32]. Like other mammals, humans are only an incidental host. The virus is endemic in Africa, Asia, and Europe [42] but also occurs in North America (the first outbreak was in 1999 in New York City) [43]. Control interventions of the West Nile virus include the elimination of mosquito breeding sites (for example, by removal of standing water where mosquitoes are likely to breed), the use of larvicides and adulticides to reduce the mosquito populations, and protection against bites [44] [45].

\subsubsection{Yellow Fever}

Yellow fever is a zoonotic viral disease transmitted by mosquitoes (Table 4). The disease has three transmission cycles: jungle transmission (monkey to monkey), savannah transmission (monkey to human) through different Aedes species (this intermediate cycle exists only in Africa) and urban transmission (human to human) through Aedes aegypti [46] [47]. In the 1980s, yellow fever re-emerged in Africa and is now endemic in the tropical regions of Africa and South America [46] [48]. The cause of the re-emergence of the disease was the insufficient immunization of the population and the increase in the density and distribution of the urban mosquito vector [47] [48]. Control strategies include mosquito control measures and preventative vaccination. 


\subsubsection{Chikungunya Fever}

Chikungunya fever is a viral disease which is transmitted by Aedes mosquitoes (Table 4) (mostly by Aedes aegypti and Aedes albopictus). Since 2004 there has been a global emergence of the disease [33] because a mutation has made it more possible for the virus to be transmitted by Aedes albopictus mosquitoes [33] [49]. Nowadays, there are massive urban outbreaks in India, South-Eastern Asia, and Africa [33], while in Europe the disease has spread up to Italy, where it emerged in 2007 [49] as a result of the expansion of A. albopictus [50]. Chikungunya outbreaks are now also reported in the Caribbean (see recent travel notices by the Centers for Disease Control and Prevention, http://www.cdc.gov/).

\subsubsection{Rift Valley Fever}

Rift Valley fever is also a viral disease [51]. It is transmitted mostly between ruminants by the bites of mosquitoes of various genera (Table 4), for example Aedes, Culex and Anopheles [34], but humans can also be infected [52]. Rift Valley fever outbreaks are periodic and are closely linked to increased rainfall or humanintroduced environmental changes like the building of dams [34] [52] [53].

\subsubsection{Onchocerciasis}

Onchocerciasis (river blindness) is caused by Onchocerca volvulus, which lives exclusively in humans [54], and is transmitted by the bites of blackflies of the genus Simulium [55] (Table 4). The disease is prevalent in Africa and America [54]. The blackflies breed in and live around fast-flowing rivers [55] (Table 4). Therefore, generally only people living in and around these areas are at risk of infection. Recently, there has been a rapid decrease in Onchocerciasis cases as a result of large public health campaigns [54]. Prevention of the disease is accomplished through vector control measures and large-scale ivermectin treatment [56] [57].

\subsubsection{Lymphatic Filariasis}

Lymphatic filariasis is caused by Wuchereria bancrofti, Brugia malayi, and Brugia timori, which live predominantly in humans [15]. The disease is transmitted by different biting mosquito species (Table 4), especially by Culex and Anopheles species [58]. More than half of the global lymphatic filariasis burden is transmitted by the mosquito species Culex quinquefasciatus [58]. In contrast to the Anopheles mosquitoes, which breed mostly in clean water [28], this species breeds in polluted water [58]. The breeding of Culex quinquefasciatus can be minimized partly by simple sanitation improvements [58]. In locations where malaria and lymphatic filariasis are co-endemic, Anopheles-control measures are likely to have more influence on lymphatic filariasis transmission. In this way, lymphatic filariasis can be eliminated as a secondary effect of malaria-vector control [58].

\section{Drivers of Water-Related Infectious Diseases}

Drivers are natural or human-introduced factors which influence the environment in ways that affect the distribution and occurrence of water-related diseases (Figure 1). We have already mentioned some factors which influence the 


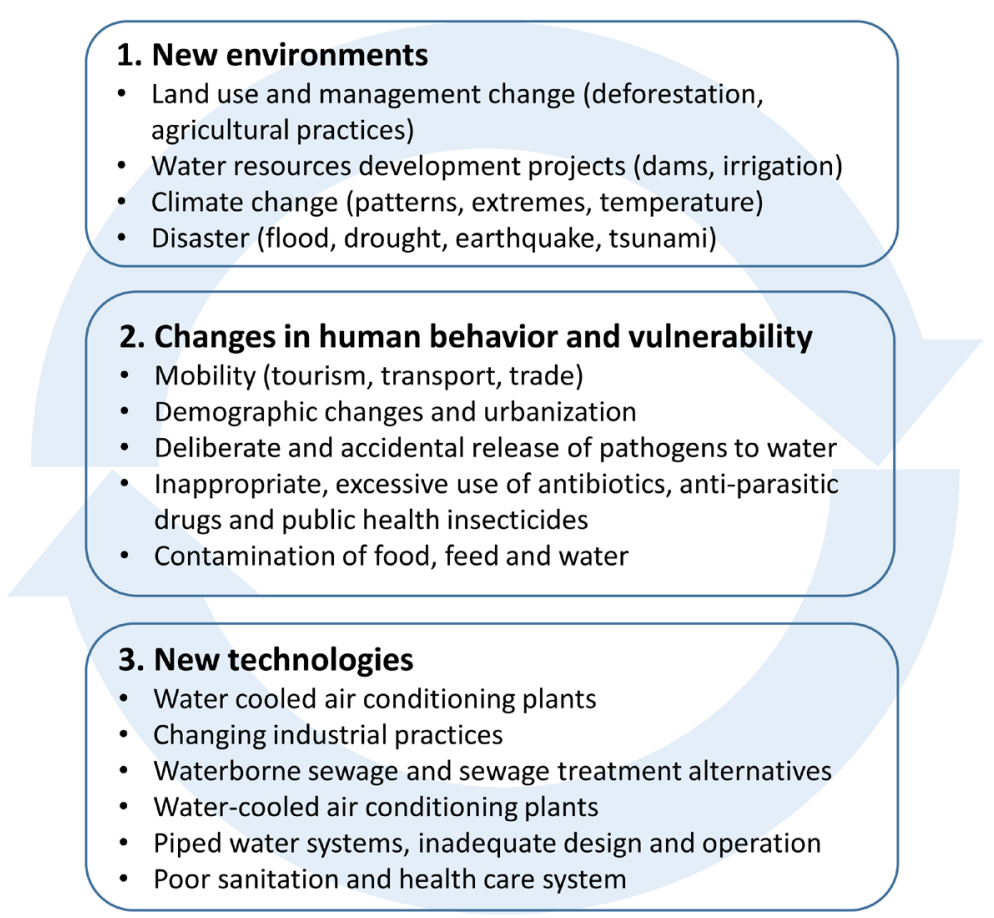

Figure 1. Potential drivers of water-related emerging and re-emerging pathogens, compiled and re-arranged from [59] [60]. Three general groups of drivers are apparent, but many of the drivers are not independent from each other.

occurrence of different water-related diseases. However, [3] further distinguishes between indirect and direct drivers. "A direct driver unequivocally influences ecosystem processes. An indirect driver operates more diffusely, by altering one or more direct drivers" [3]. In line with [3] indirect drivers are: demography, economy (e.g. globalization, trade, market, and policy framework), socio-politics (e.g. governance, institutional and legal frameworks), science and technology, culture and religion (e.g. beliefs, consumption choice). Direct drivers of change are: changes in local land use and land cover, species introduction or removal, technology adaptation and use, external inputs (e.g. fertilizer use, pest control, and irrigation), harvest and resource consumption, climate change, and finally natural, physical, and biological drivers.

[59] identify and rank ten main categories of drivers associated with emergence and re-emergence of human pathogens. Changes in land use or agricultural practices are ranked first-these are drivers that are very often associated with changes in water storage (reservoirs and dams for irrigation purposes, energy production or drinking water supply) and water flux patterns (changes in evapotranspiration and infiltration rates with effects on soil moisture storage). [60] lists potential drivers of the emergence and re-emergence of pathogens particularly related to water, with the drivers classified into four categories, i.e. new environments, changes in human behavior and vulnerability, new technologies and scientific advances. We extracted the most relevant for emerging and re-emerging pathogens in Figure 1.

In this context drivers that are most important for hydrologists are those that 
change hydrological conditions in such a way that water-related diseases occur and increase. In the following we discuss the relevance of four drivers of the $1^{\text {st }}$ and $2^{\text {nd }}$ categories (Figure 1 ) for hydrological research.

\subsection{Land Use and Management Change}

Agricultural expansion currently occurs mainly in the tropics [61]. Cleared land and new land use may form a new basis for stagnant waters (especially through erosion) which are potential breeding sites for mosquitoes [62]. Deforestation with coupled changes in land use can, for example, lead to an increase in malaria [63]. However, further, more complex, observations have been made regarding vector mosquitoes in forested sites in North Sarawak which have been cleared for palm oil production. While the risk of malaria transmission was significantly reduced by $90 \%$, prevalence of dengue vectors increased [64]. In general, there are other mosquito transmitted diseases (Table 4) that are also likely to increase due to agricultural expansion.

Changes in agriculture practices in combination with an increasing population and climate change (both are also further direct drivers which are described below) are very important. Increased need for food, feed, fuel and fiber in the future will not be only met by agricultural expansion but first of all by an intensification of land use, often through extending irrigation areas, the application of fertilizers, the use of biocides and further mechanization [61]. From a hydrological perspective, irrigation agriculture is most relevant. Extended irrigation is needed in many regions of the world e.g. in Africa irrigation equipped areas are rare [65] [66] [67] [68]. In Africa, farmers have to be encouraged to use irrigation systems and raise cropping intensity [67]. Therefore, agricultural water management needs specific attention in Africa [68]. Furthermore, [67] shows that $46 \%$ of cultivated areas in the world are not suitable for rainfed agriculture because of climate change and other meteorological conditions. Valipour [66] [69] [70] [71] [72] described the advantages and disadvantages of different irrigation methods and water management tools. Regarding the influence of vector related diseases, one must distinguish between different kinds of irrigation systems. While surface irrigation systems such as furrow, flood, or level basin techniques clearly amplify the problem by extending potential habitats, technically advanced and localized methods such as sprinkler or drip irrigation are less problematic.

\subsection{Water Resource Development Projects}

Development projects to improve or enhance water resources, such as dams and irrigation systems, are recognized as significant drivers of disease transmission. Several studies note that dams and irrigation schemes have led to the spread and occurrence of schistosomiasis and Japanese encephalitis [16] [41]. The building of dams and irrigation constructions, like irrigation channels, form new habitats highly favorable to host snails or mosquito vectors [17] [34] [73]. Irrigation results in more stagnant waters and may contribute to disease spread by connect- 
ing areas which were previously separated. Furthermore, in regions with inadequate sanitation, irrigation water can transport feces to food growing fields. As dams are often constructed for irrigation purposes, these drivers of infectious diseases are often linked.

Many studies have followed the incidence of schistosomiasis after dam construction, in particular following the construction of the Aswan Dam in Egypt [74], the Diama Dam at the mouth of the Senegal River [60] and the Three Gorges Dam in China [17].

\subsection{Climate Change}

The major effects of climate change (as a direct driver) will be rising temperature, a rise in the global average sea level, and more extremes in the hydrological cycle [4]. In [75] some impacts of climate change on malaria, encephalitis, and dengue fever are listed. The authors differentiate between the effects on vectors, pathogens, and on vertebrate hosts. On the one hand, changes in precipitation amount lead to an increase of vector populations by creating new habitats through higher rainfalls. On the other hand, excessive rainfall can also eliminate habitats through flooding, which leads to a decline of vector population. Many authors agree that mosquito-borne infections are likely to increase as a result of global warming and changes in rainfall patterns [36] [76] [77] [78]. For example, [79] show that the trend of increasing temperature could facilitate further invasions of Aedes albopictus into new regions. Other vectors or intermediate hosts like ticks, fleas, and snails may be affected in a similar way by changes in climate conditions because they are sensitive to temperature and humidity changes [78] [80] [81]. [82] estimates that global warming may increase the presence of trematodes and [83] predict that schistosomiasis will spread into currently nonendemic areas in the north of China. In regions with low temperature level or current lack of vector habitats climatic changes may in general trigger epidemics [84].

Pathogens which are directly transmitted via water will be affected by climate change through the increasing temperature and shifts in the demand for and availability of adequate water resources. For example, climate change may cause an increase in cholera bacteria through rising water temperatures [78] [85] as well as boosts in cyanobacterial blooms [76]. Outbreaks of diarrheal diseases maybe facilitated by extreme events like heavy rainfall and flooding [78] [86]. The number of food and water-borne disease cases increases with temperatures above $19.2^{\circ} \mathrm{C}$ [87].

\subsection{Demographic Changes and Urbanization}

The rapid urbanization and the population growth of the most recent decades has resulted in a lack of safe drinking water and adequate sewage systems [3] [84] [88]. Through the ingestion of or contact with contaminated water there is an increasing risk of water-related diseases especially for water based and waterborne diseases, particularly in low to middle income countries and rapidly 
growing economics such as China [24] [89] (note that the situation is however somewhat different in high income countries). Here, the risks to public health are more likely to come from infrastructure failure as a result of lack of investment in aging infrastructure [90]. Cholera infection rates, for example, are significantly higher in areas with poor sanitation [85]. There is also an increase in vector-borne diseases through uncontrolled urbanization [15] [29] [40] [88] [91]. Furthermore, urban planning often fails to account for potential public health challenges and therefore promotes disease outbreak, as was shown for dengue in Malaysia [92]. The lack of available water resources increases local efforts to set up small water storages, e.g. through rain water harvesting. Manmade containers or structures, such as rain water containing tires [40] [91] or (fish) ponds, provide ideal larvae habitats for mosquitoes. This impact fosters Aedes population densities and the transmission of Aedes-borne diseases [15], opening up potential transportation corridors for disease transmission. Increasing population and urbanization also indirectly affect other direct drivers of water-related diseases, especially changes in land use, agriculture practices and development projects, through the increasing need for water, food and human settlements.

\section{Drivers That Require Further Research}

If we want to improve our understanding of the role that hydrology and the hydrologic cycle play in determining the prevalence and spread of infectious diseases, particularly with regard to expected changes in global climate, there are several topics that require further research.

Development projects such as the installation of irrigation systems or the building of dams alter the hydrologic environment and may provide suitable habitats for malaria and lymphatic filariasis vectors [93]. The correlation between extreme hydrologic events and the occurrence of water-related diseases is a further important topic, especially with regard to climate change. Increasing precipitation with more frequent flooding and runoff events may carry pathogens into new areas and drinking water aquifers. On the one hand, in the U.S., [94] find a significant correlation between extreme precipitation events and waterborne disease outbreaks. [95] reports that enteroviruses are significantly associated with precipitation and discharge events as well and that these factors are essential in the modeling of water quality impairment. On the other hand, they found no relation between enteric protozoa and seasonal patterns. In contrast to [95], [96] report that the concentrations of enteric protozoa also increase significantly during heavy precipitation and runoff events in Germany. Discharge and bacteria concentration are not necessarily correlated because higher discharge volumes support bacterial transport, but also dilute contaminated water [97].

Finally, the goal of any disease-related research-whether the focus is on medical, social, or environmental drivers-is the reduction of the impact on humans and animals. If the drivers (Figure 1) and their effects on the environment could be fully understood, predictions on emergences or outbreaks of dis- 
eases related to hydrologic factors would be possible. Through predictions and analysis of current risk areas, limited resources could be better targeted for the control or mitigation of the effects of those diseases.

\section{Predictions of Water-Related Disease Outbreaks}

Different issues must be captured to facilitate spatio-temporal projections of water-related disease outbreaks. We have therefore outlined a conceptual model (Figure 2) that includes the required process understanding needed to consider the ecology of pathogens, their vectors and hosts as well as the internal interaction and the interaction with the environment. On catchment scale, spatially distributed water fluxes and storages play a dominant role in describing disease outbreak, transmission, and transport. New land cover types often severely alter landscape scale water storages (e.g. change of soil moisture conditions, ponding areas, addition of large reservoirs, creation of irrigation structures). Therefore, to address these different processes, they need to be captured in the model set up. Only if a comprehensive understanding of the abiotic and biotic interactions is included, models will be able to project disease outbreak for future conditions, e.g. under climate or land use change.

There are general aspects such as the understanding of the pathogen, vector, and host ecology, as well as interactions with the environmental conditions such as climate, landscape structure and land use or management, including irrigation

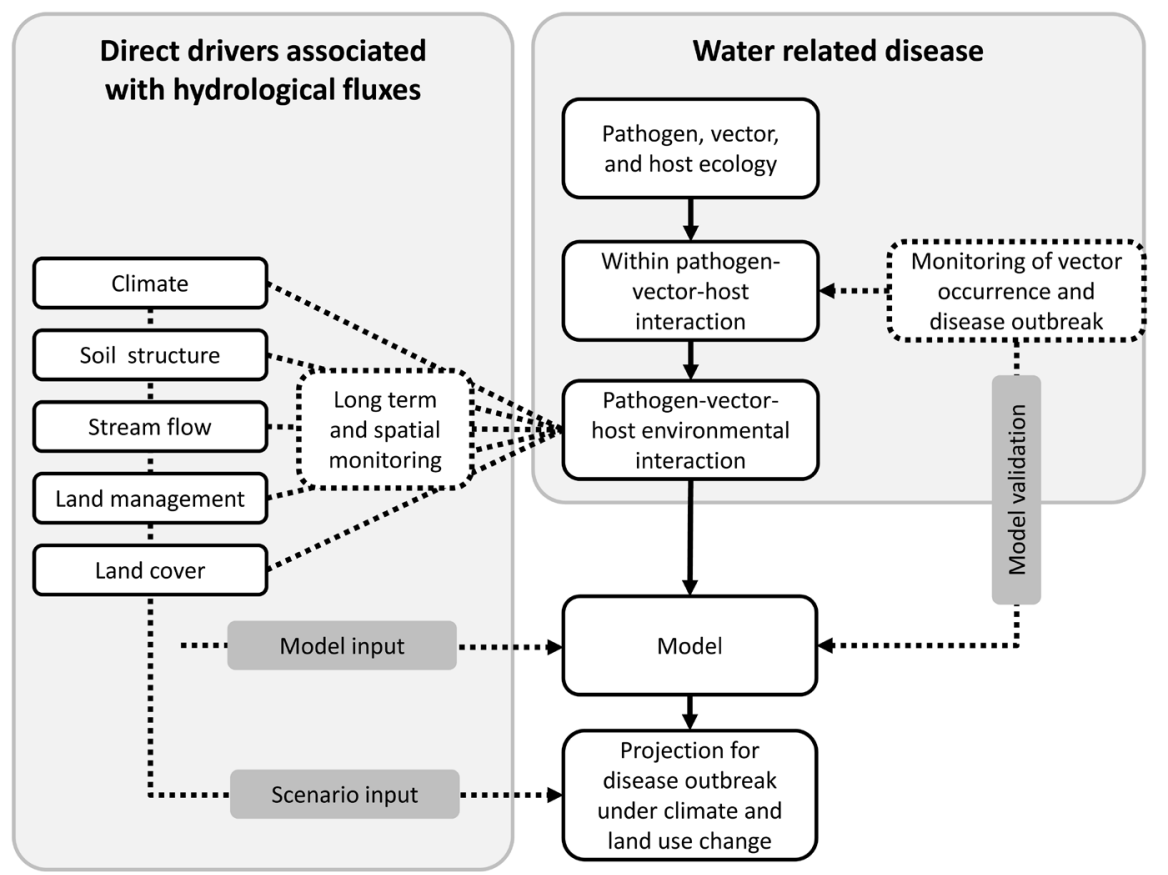

Figure 2. Conceptual model for projection of water-related disease outbreaks. Required process understanding needs to take into account the ecology of pathogens, vectors and hosts, their internal interactions, and their interaction with the environment. Spatially distributed water fluxes and storages (hydrological condition) play a dominant role in disease outbreak, transmission and transport and need to be captured in a process-based model set up. 
systems [98] [99]. For hydrologists, the temporal and spatial patterns of occurrence of pathogens and vectors related to hydrological conditions and storages (e.g. ponding water, reservoirs) are of special relevance [98] [100]. According to [101], time series models are appropriate tools for forecasting monthly rainfall in semi-arid climates. In general, models should aim at linking host-vector interactions of the water-related disease with the environmental conditions, i.e. the direct drivers that are associated with hydrology, and thereby follow the conceptual model outlined in Figure 2.

Applications of hydrologic models to understanding such dynamics include, for example, studies on the relations between the availability of mosquito breeding sites, seasonal outbreaks of mosquito populations, and mosquito-borne diseases. The relation between soil surface wetting and drying and seasonal outbreaks of mosquito populations and mosquito-borne diseases has been studied in the U.S. [99] [102] [103] and in Africa [104]. [105] develop a coupled hydrological and entomological model for Africa which simulates breeding pool formations and vector persistence.

[106] established a model of schistosomiasis transport in China, and [107] modeled snail dispersal in an endemic schistosomiasis region in Kenya, particularly following rainfall events. Valuable general suggestions for schistosomiasis modeling result from the approaches of [106] and [108]. [106] estimates transit times between specific locations of pathogens via two infectious stages of the parasite. He notes that the use of a mechanistic fate-of-pathogen model permits better extrapolation of results to other areas. [108] suggest that in any analyses of risk factors for schistosomiasis, the contact with water and the simultaneous existence of cercaria in the water should be considered. These types of studies are helpful in predicting outbreaks of diseases based on the properties of current and future local environments. In particular, understanding the connections between natural snail habitats and schistosomiasis is crucial in modelling the effects of large-scale water infrastructure projects, such as dam construction, on the disease.

Outbreaks of cholera are more easily predictable than vector-related disease outbreaks, as these depend on many more environmental factors e.g. interactions of vector and hosts [85]. Water temperature, $\mathrm{pH}$, and salinity are inter alia factors which influence the distribution of the cholera bacteria (Vibrio cholerae) [85] [109]. E.g., cholera outbreaks are modeled by [100], which includes the role of the river network in transporting Vibrio cholerae. Main processes which influence the bacteria diffusion are rainfall and flood events, temporal fluctuations of the water volume, hydrodynamic dispersion and the associated transport, the ratio of plankton and cholera bacteria, and finally, the mobility of the human population [100] [109]-[116]. [111] show that cholera outbreaks can be predicted two or three months in advance using satellite-derived chlorophyll and air temperature data in the Bengal Delta.

Further research is needed with respect to the development of predictive models. Spatial epidemiology is an important research topic and is essential for 
prediction of water-related disease outbreaks, especially for diseases which rely on water-related vectors or intermediate hosts. The impact of landscape structure on epidemiological processes has been typically neglected, but if biotic and abiotic prerequisites for diseases could be mapped, current and future disease outbreaks could be determined more accurately with regard to their spatial occurrence and timing [98]. More research is necessary to distinguish ecosystem mapping units clearly with respect to terrain, topography and hydrology [117]. Special emphasis should be given to identify, map, simulate and project the key drivers of water-related diseases (Figure 1 and Figure 2). In particular, we suggest putting more work into the linking of different research disciplines to achieve this goal, such as remote sensing, ecosystem and hydrological modeling, ecology, environmental statistics, and human and veterinary medicine.

Following [99] and [107], the coincidence of infectious diseases and events in the hydrologic cycle is a central issue for hydrologists in the combat of water-related diseases [108]. The model of [99] can be adapted to different regions through user input of parameters such as topography, vegetation and soil data. As stated by [99], additional factors like host immunity, pathogen ecology, and host-vector-pathogen interactions also have to be considered. [118] suggest that models of the ecology of $V$. cholerae have to be integrated with a model of spatial spreading within the environment and within the human host. Others have pointed out that network connectivity models, which describe the interplay between hydrology, epidemiology, and social behavior sustaining human mobility, are important for the management of waterborne infections [119]. Human mobility was further identified as an important trigger of waterborne disease outbreaks [113]. [108] recommend that, for proper prediction of water-related diseases, it is indispensable to couple a hydrologic model with an infectious disease model. For example, [120] connected their hydrological driven mosquito population model with an epidemiologic model. [108] emphasize the huge complexity in coupling disease dynamics, hydrological processes, and vector ecology determining factors.

To model pathogen and vector development it is necessary to identify the impacts of changes in the environment and/or the impacts of the occurrence of extreme hydrologic events. Identifying the drivers which cause relevant changes in the environment is also essential for prediction of future changes in the occurrence of diseases [98] [99] [121]. At this point, it is important that hydrologists, epidemiologists, and ecologists work together to achieve accurate predictions of emergences and outbreaks of diseases [98]. Finally, for the validation of models, it is essential to establish a database of monitoring data of vectors, pathogens, and disease occurrence over time.

\section{Conclusion}

To summarize, there are numerous diseases caused by pathogens which require water-related vectors or intermediate hosts, as well as diseases caused by pathogens directly transmitted via water. Studies on the dependency of these diseases 
on hydrologic processes are of high relevance for improved disease prediction in the future. As discussed in this paper, further research is needed to develop more detailed prediction models for water-related diseases, especially for the vectorand host-related diseases. Prediction models are valuable in devising adequate measures to prevent or mitigate the outbreak of a water-related disease. Hydrologic conditions and changes in these systems are of high interest for the distribution of water-related diseases [116]. Intensified collaboration between experts from different disciplines, like ecologists, hydrologists and epidemiologists, is essential for accurate prediction of water-related disease outbreaks in the future [98]. If the drivers and their effects on the environment are fully understood, predictions on emergences or outbreaks of diseases related to hydrologic factors will be possible.

\section{References}

[1] WHO (2015) World Malaria Report. World Health Organization, Geneva.

[2] WHO (2017) Schistosomiasis, Fact Sheet 115. World Health Organization, Geneva.

[3] MA (2005) Ecosystems and Human Well-Being. Island Press, Washington DC.

[4] IPCC (2013) Summary for Policymakers. Climate Change 2013: The Physical Science Basis. Contribution of Working Group I to the Fifth Assessment Report of the Intergovernmental Panel on Climate Change. Cambridge University Press, Cambridge and New York.

[5] WHO (2015) Water-Related Diseases: Information Sheets. www.who.int/water_sanitation_health/diseases/diseasefact/en/index.html

[6] NAS (2008) Safe Drinking Water Is Essential. National Academy of Science, Washington DC.

[7] WHO and UNICEF (2013) Joint Monitoring Programme-Progress on Sanitation and Drinking-Water-2013 Update. WHO/UNICEF.

[8] Bartram, J. and Cairncross, S. (2010) Hygiene, Sanitation, and Water: Forgotten Foundations of Health. PLoS Medicine, 7, e1000367. https://doi.org/10.1371/journal.pmed.1000367

[9] Cairncross, S., Bartram, J., Cumming, O. and Brocklehurst, C. (2010) Hygiene, Sanitation, and Water: What Needs to Be Done? PLoS Medicine, 7, e1000365. https://doi.org/10.1371/journal.pmed.1000365

[10] Bethony, J., Brooker, S., Albonico, M., Geiger, S.M., Loukas, A., Diemert, D. and Hotez, P.J. (2006) Soil-Transmitted Helminth Infections: Ascariasis, Trichuriasis, and Hookworm. The Lancet, 367, 1521-1532.

https://doi.org/10.1016/S0140-6736(06)68653-4

[11] Salgot, M., Huertas, E., Weber, S., Dott, W. and Hollender, J. (2006) Wastewater Reuse and Risk: Definition of Key Objectives. Desalination, 187, 29-40. https://doi.org/10.1016/j.desal.2005.04.065

[12] Steele, M. and Odumeru, J. (2004) Irrigation Water as Source of Foodborne Pathogens on Fruit and Vegetables. Journal of Food Protection, 67, 2839-2849. https://doi.org/10.4315/0362-028X-67.12.2839

[13] Hegazy, A.A., Darwish, N.M., Abdel-Hamid, I.A. and Hammad, S.M. (1999) Epidemiology and Control of Scabies in an Egyptian Village. International Journal of Dermatology, 38, 291-295. https://doi.org/10.1046/j.1365-4362.1999.00630.x

[14] Studt, H.H. (2003) Allgemeine und spezielle Infektionslehre: Infektionskrankheiten- 
Mikrobiologie-Parasitologie-Hygiene. Kohlhammer, Stuttgart.

[15] WHO (2010) Working to Overcome the Global Impact of Neglected Tropical Diseases. First WHO Report on Neglected Tropical Diseases. World Health Organization, Geneva.

[16] Chitsulo, L., Engels, D., Montresor, A. and Savioli, L. (2000) The Global Status of Schistosomiasis and Its Control. Acta Tropica, 77, 41-51. https://doi.org/10.1016/S0001-706X(00)00122-4

[17] Steinmann, P., Keiser, J., Bos, R., Tanner, M. and Utzinger, J. (2006) Schistosomiasis and Water Resources Development: Systematic Review, Meta-Analysis, and Estimates of People at Risk. The Lancet Infectious Diseases, 6, 411-425. https://doi.org/10.1016/S1473-3099(06)70521-7

[18] Fenwick, A. (2006) Waterborne Infectious Diseases-Could They Be Consigned to History? Science, 313, 1077-1081. https://doi.org/10.1126/science.1127184

[19] Appleton, C.C. and Madsen, H. (2012) Human Schistosomiasis in Wetlands in Southern Africa. Wetlands Ecology and Management, 20, 253-269. https://doi.org/10.1007/s11273-012-9266-2

[20] Wenk, P. and Renz, A. (2003) Biologie der Humanparasiten. Georg Thieme, Stuttgart.

[21] WHO (2009) Elimination of Schistosomiasis from Low-Transmission Areas. Report of a WHO Informal Consultation. World Health Organization, Geneva.

[22] WHO (2008) Eradicating Guinea-Worm Disease. World Health Organization, Geneva.

[23] WHO (2013) Dracunculiasis: Annual Incidence of Cases by Country. World Health Organization, Geneva.

[24] Lee, E.J. and Schwab, K.J. (2005) Deficiencies in Drinking Water Distribution Systems in Developing Countries. Journal of Water Health, 3, 109-127.

[25] Visser, B.J. (2012) Dracunculiasis Eradication-Finishing the Job before Surprises Arise. Asian Pac. Journal of Tropical Medicine, 5, 505-510.

https://doi.org/10.1016/S1995-7645(12)60088-1

[26] WHO (1988) Environmental Management for Vector Control: Training and Informational Materials. Slide Set Series. PART B: Water-Associates Vector-Borne Diseases, with the Emphasis on the Vector. WHO.

http://www.who.int/water_sanitation_health/resources/vectcont/en/

[27] Tuteja, R. (2007) Malaria-An Overview. FEBS Journal, 274, 4670-4679. https://doi.org/10.1111/j.1742-4658.2007.05997.x

[28] Lindsay, S., Bos, R., Kirby, M. and Baris, E. (2004) Environmental Management for Malaria Control in the East Asia and Pacific (EAP) Region. The World Bank, Washington DC.

[29] WHO (2010) World Malaria Report 2010. World Health Organization, Geneva.

[30] WHO (2013) World Malaria Report. World Health Organization, Geneva.

[31] WHO (2013) Malaria, Fact Sheet 94. World Health Organization, Geneva.

[32] Campbell, G.L., Marfin, A.A., Lanciotti, R.S. and Gubler, D.J. (2002) West Nile virus. The Lancet Infectious Diseases, 2, 519-529. https://doi.org/10.1016/S1473-3099(02)00368-7

[33] Simon, F., Javelle, E., Oliver, M., Leparc-Goffart, I. and Marimoutou, C. (2011) Chikungunya Virus Infection. Current Infectious Diseases Report, 13, 218-228. https://doi.org/10.1007/s11908-011-0180-1

[34] Kuhn, K., Campbell-Lendrum, D., Haines, A. and Cox, J. (2005) Using Climate to 
Predict Infectious Disease Epidemics. WHO, Geneva.

[35] WHO (2016) Zika Virus. Technical Report. World Health Organization, Geneva.

[36] Patz, J.A. (2002) A Human Disease Indicator for the Effects of Recent Global Climate Change. Proceedings of the National Academy of Sciences, 99, 12506-12508. https://doi.org/10.1073/pnas.212467899

[37] Faye, O., Freire, C.C.M., Iamarino, A., Faye, O., de Oliveira, J.V.C., Diallo, M., Zanotto, P.M.A. and Sall, A.A. (2014) Molecular Evolution of Zika Virus during Its Emergence in the 20th Century. PLoS Neglected Tropical Diseases, 8, e2636. https://doi.org/10.1371/journal.pntd.0002636

[38] Bogoch, I.I., Brady, O.J., Kraemer, M.U.G., German, M., Creatore, M.I., Kulkarni, M.A., Brownstein, J.S., Mekaru, S.R., Hay, S.I., Groot, E., Watts, A. and Khan K. (2016) Anticipating the International Spread of Zika Virus from Brazil. The Lancet, 387, 335-336. https://doi.org/10.1016/S0140-6736(16)00080-5

[39] Plourde, A.R. and Bloch, E.M. (2016) Literature Review of Zika Virus. Emerging Infectious Diseases, 22, 1185-1192. https://doi.org/10.3201/eid2207.151990

[40] Mackenzie, J.S., Gubler, D.J. and Petersen, L.R. (2004) Emerging Flaviviruses: The Spread and Resurgence of Japanese Encephalitis, West Nile and Dengue Viruses. Nature Medicine, 10, S98-S109. https://doi.org/10.1038/nm1144

[41] Keiser, J., Maltese, M.F., Erlanger, T.E., Bos, R., Tanner, M., Singer, B.H. and Utzinger, J. (2005) Effect of Irrigated Rice Agriculture on Japanese Encephalitis, Including Challenges and Opportunities for Integrated Vector Management. Acta Tropica, 95, 40-57. https://doi.org/10.1016/j.actatropica.2005.04.012

[42] Hubalek, Z. and Halouzka, J. (1999) West Nile Fever-A Reemerging Mosquito-Borne Viral Disease in Europe. Emerging Infectious Diseases, 5, 643-650. https://doi.org/10.3201/eid0505.990506

[43] Nash, D., Mostashari, F., Fine, A., Miller, J., O’Leary, D., Murray, K., Huang, A., Rosenberg, A., Greenberg, A., Sherman, M., Wong, S., Campbell, G.L., Roehrig, J.T., Gubler, D.J., Shieh, W.-J., Zaki, S., Smith, P. and Layton, M. (2001) The Outbreak of West Nile Virus Infection in the New York City Area in 1999. New England Journal of Medicine, 344, 1807-1814. https://doi.org/10.1056/NEJM200106143442401

[44] Nosal, B. and Pellizzari, R. (2003) West Nile Virus. Canadian Medical Association Journal, 168, 1443-1444.

[45] Petersen, J.R., Marfin, A.A. and Gubler, D. (2003) West Nile Virus. JAMA, 290, 524-528. https://doi.org/10.1001/jama.290.4.524

[46] CDC (2010) Yellow Fever Vaccine. Morbidity and Mortality Weekly Report, 59, 612.

[47] Monath, T.P. (2001) Yellow Fever: An Update. Lancet Infectious Diseases, 1, 11-20. https://doi.org/10.1016/S1473-3099(01)00016-0

[48] WHO (2005) Progress in the Control of Yellow Fever in Africa. Weekly Epidemiological Record, 80, 50-55.

[49] Mackenzie, J.S. (2011) Responding to Emerging Diseases: Reducing the Risks through Understanding of Emergence. Western Pacific Surveillance and Response Journal, 2, 1-5.

[50] Enserink, M. (2007) Tropical Disease Follows Mosquitoes to Europe. Science, 317, 1485. https://doi.org/10.1126/science.317.5844.1485a

[51] Anyamba, A., Chretien, J.-P., Small, J., Tucker, C.J., Formenty, P.B., Richardson, J.H., Britch, S.C., Schnabel, D.C., Erickson, R.L. and Linthicum, K.J. (2009) Prediction of a Rift Valley Fever Outbreak. Proceedings of the National Academy of Sciences, 106, 955-959. https://doi.org/10.1073/pnas.0806490106 
[52] Andriamandimby, S.F., Randrianarivo-Solofoniaina, A.E., Jeanmaire, E.M., Ravololomanana, L., Razafimanantsoa, L.T., Rakotojoelinandrasana, T., Razainirina, J., Hoffmann, J., Ravalohery, J.-P., Rafisandratantsoa, J.-T., Rollin, P.E. and Reynes, J.-M. (2010) Rift Valley Fever during Rainy Seasons, Madagascar, 2008 and 2009. Emerging Infectious Diseases, 16, 963-970. https://doi.org/10.3201/eid1606.091266

[53] Davies, F.G., Linthicum, K.J. and James, A.D. (1985) Rainfall and Epizootic Rift Valley Fever. Bulletin of the World Health Organization, 63, 941-943.

[54] Winthrop, K.L., Furtado, J.M., Silva, J.C., Resnikoff, S. and Lansingh, V.C. (2011) River Blindness: An Old Disease on the Brink of Elimination and Control. Journal of Global Infectious Diseases, 3, 151-155. https://doi.org/10.4103/0974-777X.81692

[55] WHO (2010) African Programme for Onchocerciasis Control-Report of the Sixth Meeting of National Task Forces, October 2009. The Weekly Epidemiological Record, 85, 21-28.

[56] Diawara, L., Traoré, M.O., Badji, A., Bissan, Y., Doumbia, K., Goita, S.F., Konaté, L., Mounkoro, K., Sarr, M.D., Seck, A.F., Toé, L., Tourée, S. and Remme, J.H.F. (2009) Feasibility of Onchocerciasis Elimination with Ivermectin Treatment in Endemic Foci in Africa: First Evidence from Studies in Mali and Senegal. PLoS Neglected Tropical Diseases, 3 e497. https://doi.org/10.1371/journal.pntd.0000497

[57] Remme, J.H., Feenstra, P., Lever, P.R., Medici, A., Morel, C., Noma, M., Ramaiah, K.D., Richards, F., Seketeli, A., Schmunis, G., van Brakel, W.H. and Vassall, A. (2006) Tropical Diseases Targeted for Elimination: Chagas Disease, Lymphatic Filariasis, Onchocerciasis, and Leprosy. Vol. 22, Oxford University Press, New York, 433-447.

[58] Zagaria, N. and Savioli, L. (2002) Elimination of Lymphatic Filariasis: A Public-Health Challenge. Annals of Tropical Medicine and Parasitology, 96, 3-13. https://doi.org/10.1179/00034980215002347

[59] Woolhouse, M.E.J. and Gowtage-Sequeria, S. (2005) Host Range and Emerging and Reemerging Pathogens. Emerging Infectious Diseases, 11, 1842-1847. https://doi.org/10.3201/eid1112.050997

[60] WHO (2003) Emerging Issues in Water and Infectious Disease. World Health Organization, Geneva.

[61] Foley, J.A., Ramankutty, N., Brauman, K.A., Cassidy, E.S., Gerber, J.S., Johnston, M., Mueller, N.D., O’Connell, C., Ray, D.K., West, P.C., Balzer, C., Bennett, E.M., Carpenter, S.R., Hill, J., Monfreda, C., Polasky, S., Rockström, J., Sheehan, J., Siebert, S., Tilman, D. and Zaks, D.P.M. (2011) Solutions for a Cultivated Planet. Nature, 478, 337-342. https://doi.org/10.1038/nature10452

[62] Marques, C.A. (1987) Human Migration and the Spread of Malaria in Brazil. Parasitology Today, 3, 166-170. https://doi.org/10.1016/0169-4758(87)90170-0

[63] Patz, J.A., Daszak, P., Tabor, G.M., Aguirre, A.A., Pearl, M., Epstein, J., Wolfe, N.D., Kilpatrick, A.M., Foufopoulos, J., Molyneux, D. and Bradley, D.J. (2004) Unhealthy Landscapes: Policy Recommendations on Land Use Change and Infectious Disease Emergence. Environmental Health Perspectives, 112, 1092-1098. https://doi.org/10.1289/ehp.6877

[64] Chang, M.S., Hii, J., Buttner, P. and Mansoor, F. (1997) Changes in Abundance and Behaviour of Vector Mosquitoes Induced by Land Use during the Development of an Oil Palm Plantation in Sarawak. Transactions of the Royal Society of Tropical Medicine and Hygiene, 91, 382-386. https://doi.org/10.1016/S0035-9203(97)90248-0

[65] Valipour, M. (2013) Evolution of Irrigation-Equipped Areas as Share of Cultivated Area. Irrigation \& Drainage Systems Engineering, 2, e114.

[66] Valipour, M. (2013) Necessity of Irrigated and Rainfed Agriculture in the World. 
Irrigation \& Drainage Systems Engineering, S9, e001. https://doi.org/10.4172/2168-9768.S9-e001

[67] Valipour, M. (2015) Land Use Policy and Agricultural Water Management of the Previous Half of Century in Africa. Applied Water Science, 5, 367-395. https://doi.org/10.1007/s13201-014-0199-1

[68] Valipour, M. (2015) Future of Agricultural Water Management in Africa. Archives of Agronomy and Soil Science, 61, 907-927. https://doi.org/10.1080/03650340.2014.961433

[69] Valipour, M. (2012) Comparison between Horizontal and Vertical Drainage Systems (Include Pipe Drainage, Open Ditch Drainage, and Pumped Wells) in Anisotropic Soils. Journal of Mechanical and Civil Engineering, 4, 7-12. https://doi.org/10.9790/1684-0410712

[70] Valipour, M. (2012) Hydro-Module Determination for Vanaei Village in Eslam Abad Gharb, Iran. Journal of Agricultural and Biological Science, 7, 968-976.

[71] Valipour, M. (2013) Use of Surface Water Supply Index to Assessing of Water Resources Management in Colorado and Oregon, US. Advances in Agriculture, Sciences and Engineering Research, 3, 631-640.

[72] Valipour, M. (2013) Increasing Irrigation Efficiency by Management Strategies: Cutback and Surge Irrigation. Journal of Agricultural and Biological Science, 8, 35.

[73] Patz, J.A., Graczyk, T.K., Geller, N. and Vittor, A.Y. (2000) Effects of Environmental Change on Emerging Parasitic Diseases. International Journal of Parasitology, 30, 1395-1405. https://doi.org/10.1016/S0020-7519(00)00141-7

[74] Malek, E.A. (1975) Effect of the Aswan High Dam on Prevalence of Schistosomiasis in Egypt. Tropical and Geographical Medicine, 27, 359-364.

[75] Gubler, D.J., Reiter, P., Ebi, K.L., Yap, W., Nasci, R. and Patz, J.A. (2001) Climate Variability and Change in the United States: Potential Impacts on Vector- and Rodent-Borne Diseases. Environmental Health Perspectives, 109, 223-233. https://doi.org/10.2307/3435012

[76] Hunter, P.R. (2003) Climate Change and Waterborne and Vector-Borne Disease. Journal of Applied Microbiology, 94, 37-46. https://doi.org/10.1046/j.1365-2672.94.s1.5.x

[77] Lindsay, S.W. and Martens, W.J. (1998) Malaria in the African Highlands: Past, Present and Future. Bulletin of the World Health Organization, 76, 33-45.

[78] McMichael, A.J., Woodruff, R.E. and Hales, S. (2006) Climate Change and Human Health: Present and Future Risks. The Lancet, 367, 859-869. https://doi.org/10.1016/S0140-6736(06)68079-3

[79] Roiz, D., Neteler, M., Castellani, C., Arnoldi, D. and Rizzoli, A. (2011) Climatic Factors Driving Invasion of the Tiger Mosquito (Aedes albopictus) into New Areas of Trentino, Northern Italy. PLOS ONE, 6, e14800. https://doi.org/10.1371/journal.pone.0014800

[80] Haines, A. and Patz, J.A. (2004) Health Effects of Climate Change. JAMA, 291, 99103. https://doi.org/10.1001/jama.291.1.99

[81] Lindgren, E., Talleklint, L. and Polfeldt, T. (2000) Impact of Climatic Change on the Northern Latitude Limit and Population Density of the Disease-Transmitting European Tick Ixodes ricinus. Environmental Health Perspectives, 108, 119-123. https://doi.org/10.1289/ehp.00108119

[82] Poulin, R. (2006) Global Warming and Temperature-Mediated Increases in Cercarial Emergence in Trematode Parasites. Parasitology, 132, 143-151.

https://doi.org/10.1017/s0031182005008693 
[83] Zhou, X.-N., Yang, G.-J., Yang, K., Wang, X.-H., Hong, Q.-B., Sun, L.-P., Malone, J.B., Kristensen, T.K., Bergquist, N.R. and Utzinger, J. (2008) Potential Impact of Climate Change on Schistosomiasis Transmission in China. The American Journal of Tropical Medicine and Hygiene, 78, 188-194.

[84] Global Environmental Change and Human Health (2007) Science Plan and Implementation Strategy. Earth System Science Partnership (DIVERSITAS, IGBP, IHDP, and WCRP) Report No. 4; Global Environmental Change and Human Health Report No.1

[85] Lipp, E.K., Huq, A. and Colwell, R.R. (2002) Effects of Global Climate on Infectious Disease: The Cholera Model. Clinical Microbiological Reviews, 15, 757-770. https://doi.org/10.1128/CMR.15.4.757-770.2002

[86] Griffith, D.C., Kelly-Hope, L.A. and Miller, M.A. (2006) Review of Reported Cholera Outbreaks Worldwide, 1995-2005. The American Journal of Tropical Medicine and Hygiene, 75, 973-977.

[87] El-Fadel, M., Ghanimeh, S., Maroun, R. and Alameddine, I. (2012) Climate Change and Temperature Rise: Implications on Food- and Water-Borne Diseases. Science of the Total Environment, 437, 15-21. https://doi.org/10.1016/j.scitotenv.2012.07.041

[88] Knudsen, A.B. and Slooff, R. (1992) Vector-Borne Disease Problems in Rapid Urbanization: New Approaches to Vector Control. Bulletin World Health Organization, 70, 1-6.

[89] Wu, C.H., Maurer, C., Wang, Y., Xue, S.Z. and Davis, D.L. (1999) Water Pollution and Human Health in China. Environmental Health Perspectives, 107, 251-256. https://doi.org/10.1289/ehp.99107251

[90] Craun, G.F., Brunkard, J.M., Yoder, J.S., Roberts, V.A., Carpenter, J., Wade, T., Calderon, R.L., Roberts, J.M., Beach, M.J. and Roy, S.L. (2010) Causes of Outbreaks Associated with Drinking Water in the United States from 1971 to 2006. Clinical Microbiological Reviews, 23, 507-528. https://doi.org/10.1128/CMR.00077-09

[91] Gubler, D.J. (1989) Aedes aegypti and Aedes aegypti-Borne Disease Control in the 1990s: Top Down or Bottom Up. American Journal of Tropical Medicine and $\mathrm{Hy}$ giene, 40, 571-578.

[92] Mulligan, K., Elliott, S.J. and Schuster-Wallace, C.J. (2012) Global Public Health Policy Transfer and Dengue Fever in Putrajaya, Malaysia: A Critical Discourse Analysis. Critical Public Health, 22, 407-418. https://doi.org/10.1080/09581596.2012.659722

[93] Erlanger, T.E., Keiser, J., Castro, M.C.D., Bos, R., Singer, B.H., Tanner, M. and Utzinger, J. (2005) Effect of Water Resource Development and Management on Lymphatic Filariasis, and Estimates of Populations at Risk. The American Journal of Tropical Medicine and Hygiene, 73, 523-533.

[94] Curriero, F.C., Patz, J.A., Rose, J.B. and Lele, S. (2001) The Association between Extreme Precipitation and Waterborne Disease Outbreaks in the United States, 1948-1994. American Journal of Public Health, 91, 1194-1199.

https://doi.org/10.2105/AJPH.91.8.1194

[95] Lipp, E.K., Kurz, R., Vincent, R., Rodriguez-Palacios, C., Farrah, S.R. and Rose, J.B. (2001) The Effects of Seasonal Variability and Weather on Microbial Fecal Pollution and Enteric Pathogens in a Subtropical Estuary. Estuaries, 24, 266-276. https://doi.org/10.2307/1352950

[96] Kistemann, T., Claßen, T., Koch, C., Dangendorf, F., Fischeder, R., Gebel, J., Vacata, V. and Exner, M. (2002) Microbial Load of Drinking Water Reservoir Tributaries during Extreme Rainfall and Runoff. Applied Environmental Microbiology, 68, 2188-2197. https://doi.org/10.1128/AEM.68.5.2188-2197.2002 
[97] Pronk, M., Goldscheider, N. and Zopfi, J. (2006) Dynamics and Interaction of Organic Carbon, Turbidity and Bacteria in a Karst Aquifer System. Hydrogeology Journal, 14, 473-484. https://doi.org/10.1007/s10040-005-0454-5

[98] Ostfeld, R.S., Glass, G.E. and Keesing, F. (2005) Spatial Epidemiology: An Emerging (or Re-Emerging) Discipline. Trends in Ecology \& Evolution, 20, 328-336. https://doi.org/10.1016/j.tree.2005.03.009

[99] Shaman, J., Stieglitz, M., Stark, C., Le Blancq, S. and Cane, M. (2002) Using a Dynamic Hydrology Model to Predict Mosquito Abundances in Flood and Swamp Water. Emerging Infectious Diseases, 8, 8-13. https://doi.org/10.3201/eid0801.010049

[100] Bertuzzo, E., Azaele, S., Maritan, A., Gatto, M., Rodriguez-Iturbe, I. and Rinaldo, A. (2008) On the Space-Time Evolution of a Cholera Epidemic. Water Resources Research, 44, W01424. https://doi.org/10.1029/2007WR006211

[101] Valipour, M. (2016) How Much Meteorological Information Is Necessary to Achieve Reliable Accuracy for Rainfall Estimations? Agriculture, 6, 2-9. https://doi.org/10.3390/agriculture6040053

[102] Shaman, J., Day, J.F. and Stieglitz, M. (2004) The Spatial-Temporal Distribution of Drought, Wetting, and Human Cases of St. Louis Encephalitis in South Central Florida. The American Journal of Tropical Medicine and Hygiene, 71, 251-261.

[103] Shaman, J., Day, J.F. and Stieglitz, M. (2005) Drought-Induced Amplification and Epidemic Transmission of West Nile Virus in Southern Florida. Journal of Medical Entomology, 42, 134-141. https://doi.org/10.1093/jmedent/42.2.134

[104] Patz, J.A. (1998) Predicting Key Malaria Transmission Factors, Biting and Entomological Inoculation Rates, Using Modelled Soil Moisture in Kenya. Tropical Medicine \& International Health, 3, 818-827. https://doi.org/10.1046/j.1365-3156.1998.00309.x

[105] Bomblies, A., Duchemin, J.-B. and Eltahir, E.A.B. (2008) Hydrology of Malaria: Model Development and Application to a Sahelian Village. Water Resources Research, 44, W12445. https://doi.org/10.1029/2008WR006917

[106] Maszle, D.R., Whitehead, P.G., Johnson, R.C. and Spear, R.C. (1998) Hydrological Studies of Schistosomiasis Transport in Sichuan Province, China. Science of the Total Environment, 216, 193-203. https://doi.org/10.1016/S0048-9697(98)00152-1

[107] Clennon, J.A., King, C.H., Muchiri, E.M. and Kitron, U. (2007) Hydrological Modelling of Snail Dispersal Patterns in Msambweni, Kenya and Potential Resurgence of Schistosoma haematobium Transmission. Parasitology, 134, 683-693. https://doi.org/10.1017/S0031182006001594

[108] Remais, J., Liang, S. and Spear, R.C. (2008) Coupling Hydrologic and Infectious Disease Models to Explain Regional Differences in Schistosomiasis Transmission in Southwestern China. Environmental Science \& Technology, 42, 2643-2649. https://doi.org/10.1021/es071052s

[109] Koelle, K., Rodó, X., Pascual, M., Yunus, M. and Mostafa, G. (2005) Refractory Periods and Climate Forcing in Cholera Dynamics. Nature, 436, 696-700. https://doi.org/10.1038/nature03820

[110] Jutla, A.S., Akanda, A.S. and Islam, S. (2010) Tracking Cholera in Coastal Regions Using Satellite Observations. Journal of the American Water Resources Association, 46, 651-662. https://doi.org/10.1111/j.1752-1688.2010.00448.x

[111] Jutla, A.S., Akanda, A.S. and Islam, S. (2013) A Framework for Predicting Endemic Cholera Using Satellite Derived Environmental Determinants. Environmental Modelling \& Software, 47, 148-158. https://doi.org/10.1016/j.envsoft.2013.05.008 
[112] Mari, L., Bertuzzo, E., Righetto, L., Casagrandi, R., Gatto, M., Rodriguez-Iturbe, I. and Rinaldo, A. (2012) Modelling Cholera Epidemics: The Role of Waterways, $\mathrm{Hu}-$ man Mobility and Sanitation. Journal of the Royal Society Interface, 9, 376-388. https://doi.org/10.1098/rsif.2011.0304

[113] Mari, L., Bertuzzo, E., Righetto, L., Casagrandi, R., Gatto, M., Rodriguez-Iturbe, I. and Rinaldo, A. (2012) On the Role of Human Mobility in the Spread of Cholera Epidemics: Towards an Epidemiological Movement Ecology. Ecohydrology, 5, 531540. https://doi.org/10.1002/eco.262

[114] Righetto, L., Bertuzzo, E., Casagrandi, R., Gatto, M., Rodriguez-Iturbe, I. and Rinaldo, A. (2011) Modelling Human Movement in Cholera Spreading along Fluvial Systems. Ecohydrology, 4, 49-55. https://doi.org/10.1002/eco.122

[115] Righetto, L., Casagrandi, R., Bertuzzo, E., Mari, L., Gatto, M., Rodriguez-Iturbe, I. and Rinaldo, A. (2012) The Role of Aquatic Reservoir Fluctuations in Long-Term Cholera Patterns. Epidemics, 4, 33-42. https://doi.org/10.1016/j.epidem.2011.11.002

[116] Righetto, L., Bertuzzo, E., Mari, L., Schild, E., Casagrandi, R., Gatto, M., Rodriguez-Iturbe, I. and Rinaldo, A. (2013) Rainfall Mediations in the Spreading of Epidemic Cholera. Advances in Water Resources, 60, 34-46. https://doi.org/10.1016/j.advwatres.2013.07.006

[117] Githeko, A.K., Ototo, E.N. and Guiyun, Y. (2012) Progress towards Understanding the Ecology and Epidemiology of Malaria in the Western Kenya Highlands: Opportunities and Challenges for Control under Climate Change Risk. Acta Tropica, 121, 19-25. https://doi.org/10.1016/j.actatropica.2011.10.002

[118] Bertuzzo, E., Mari, L., Righetto, L., Gatto, M., Casagrandi, R., Rodriguez-Iturbe, I. and Rinaldo, A. (2012) Hydroclimatology of Dual-Peak Annual Cholera Incidence: Insights from a Spatially Explicit Model. Geophysical Research Letters, 39, L05403. https://doi.org/10.1029/2011GL050723

[119] Gatto, M., Mari, L., Bertuzzo, E., Casagrandi, R., Righetto, L., Rodriguez-Iturbe, I. and Rinaldo, A. (2012) Generalized Reproduction Numbers and the Prediction of Patterns in Waterborne Disease. Proceedings of the National Academy of Sciences, 109, 19703-19708. https://doi.org/10.1073/pnas.1217567109

[120] Shaman, J., Spiegelman, M., Cane, M. and Stieglitz, M. (2006) A Hydrologically Driven Model of Swamp Water Mosquito Population Dynamics. Ecological Modelling, 194, 395-404. https://doi.org/10.1016/j.ecolmodel.2005.10.037

[121] Rogers, D.J., Randolph, S.E., Snow, R.W. and Hay, S.I. (2002) Satellite Imagery in the Study and Forecast of Malaria. Nature, 415, 710-715.

https://doi.org/10.1038/415710a 
Submit or recommend next manuscript to SCIRP and we will provide best service for you:

Accepting pre-submission inquiries through Email, Facebook, LinkedIn, Twitter, etc. A wide selection of journals (inclusive of 9 subjects, more than 200 journals)

Providing 24-hour high-quality service

User-friendly online submission system

Fair and swift peer-review system

Efficient typesetting and proofreading procedure

Display of the result of downloads and visits, as well as the number of cited articles Maximum dissemination of your research work

Submit your manuscript at: http://papersubmission.scirp.org/

Or contact jwarp@scirp.org 